\title{
Når idrett og helse kolliderer
}

\author{
Det kan være kolliderende interesser mellom helse og prestasjoner innen idrett. Dette gjelder ikke minst \\ ernæring, med fare for feilernæring og/eller underernæring.
}

\section{Finn Skårderud \\ finns@online.no \\ Terje Fladvad \\ Ina Garthe \\ Heidi Holmlund \\ Lars Engebretsen}

Idrett, og især toppidrett, er risikomiljøer for forstyrret spiseatferd. Idrett og spiseforstyrrelser kan $\mathrm{i}$ en viss grad forstås som «søskenkulturer». Begge kretser om kropp, prestasjon, perfeksjon og ernæring. Gjennom vårt arbeid ved Olympiatoppen ser vi et mangfold av problematiske forhold til mat og kropp. Vi tenker at noen er feil- eller underernærte fordi de mangler kunnskap om hva som er riktig og nødvendig ernæring for en topputøver med et meget høyt aktivitetsnivå. Andre spiser med hensikt for lite da de aktivt søker en lavere vekt eller å opprettholde en kunstig lav vekt de tror gir en prestasjonsfordel $(1,2)$.

I vektklasseidretter er det vanlig at utøvere «piner vekt» for å oppnå prestasjonsmessige fordeler ved å konkurrere i lavere vektklasser (3). Utøvere i slike idretter kan begynne med vektreduksjon allerede i 9-14 års alder (3-6). Vår erfaring er at unge utøvere har et dårligere støtteapparat og mindre muligheter for både å bli sett og å få adekvat behandling, noe som sammen med økt sårbarhet gjør den medisinske risikoen større enn hos voksne utøvere på høyt nivå. Og det ser ut til å være sammenhenger mellom hvor tidlig vektreduksjonen starter og anvendelse av mer ekstreme vektreduksjonsmetoder senere i idrettskarrieren (6).

For noen vil feil- og/eller underernæring være av en slik alvorlighetsgrad at det kan diagnostiseres som spiseforstyrrelse $(7,8)$. Uheldig praksis kan føre til medisinsk skade, men det rammer også det idrettslige, både prestasjoner og trivsel.

Forfatterne inngår $i$ et spesialteam for ernæring og spiseforstyrrelser ved Olympiatoppen og har nylig utarbeidet retningslinjer for trening og konkurranse i forbindelse med dårlig ernæring $(9,10)$. I denne kronikken ønsker vi gjennom kasuistikker å få frem bredden i temaet og vise til gode erfaringer med å håndtere slike problemer.

\section{Ernæring som kompetanse}

Utøver A hadde manglende fremgang i sin idrett. Det siste halve året hadde han gått ned fire kilo, og det var påvist redusert testosteronnivå. A hadde økt treningsmengden, $ø$ øt inntaket av sunne matvarer som frukt og grønnsaker og redusert inntaket av søtsaker. Iveren etter å gjøre «alt riktig» førte til utilstrekkelig inntak av både energi og karbohydrater. Dette fikk altså både helseog prestasjonsmessige konsekvenser for ham. A fikk en kostplan som tilfredsstilte hans oppdaterte behov med krav til vekt$ø k n i n g$. Testosteronnivåene ble da gradvis normalisert. Han var i full trening etter noen uker, og prestasjonene ble merkbart bedre.

Eksemplet viser at spiseproblemer også rammer gutter og menn. Et tidvis ensidig fokus på spiseforstyrrelser som et feminint problem kan bidra til manglende kompetanse og årvåkenhet for slike problemer hos gutter og menn (11).

I idrettsmedisin har det vært mye oppmerksomhet rundt kvinnelige utøvere og den såkalte «kvinnelige utøvertriaden». Dette begrepet viser til en kombinasjon av symptomer på spiseforstyrrelser og amenoré med tilhørende risiko for redusert beinhelse (osteopeni, osteoporose) hos utøvere. Vi vil her utvide et slikt fokus til også å gjelde menn med liknende problematikk, forslagsvis en «mannlig utøvertriade». De studier som er gjort på mannlige utøvere i forhold til vektregulering og forstyrret spiseatferd tyder på at de er utsatt for beslektede problemer som kvinnene. Lav energitilgjengelighet og lav fettprosent reduserer nivået av det mannlige kjønnshormonet testosteron (12), og det er rapportert redusert testosteronnivå hos mannlige brytere og langdistanseløpere (13-15). Måling og vurdering av testosteron er imidlertid alt annet enn entydig, og grensene for lave og normale verdier er ikke klare, selv om laboratoriene angir grenseverdier.

Det finnes ennå ingen studier der man har undersøkt alle tre variablene for eventuell triadeproblematikk hos menn samtidig, så man skal være varsom med å trekke konklusjoner. Samtidig rapporteres det om lav beinmineraltetthet (BMD) hos både langdistanseløpere og syklister $(16,17)$. Det er rapportert at så mange som $63 \%$ av mann- lige syklister ble diagnostisert med redusert beinmasse, osteopeni (17). Vi mener at det er viktig å være spesielt oppmerksom på de mannlige utøverne med «triade»-symptomer og dermed tilby tilsvarende oppfølging og behandling som de kvinnelige utøverne med triadeproblematikk.

\section{Den anorektiske utøveren}

Utøver B viste klare tegn på anoreksi. Samtidig var $B$ en av de beste på laget. Dette skapte mye uro. Det var uklart hvorvidt hun faktisk manglet sykdomsinnsikt eller hvorvidt hun hadde en slik innsikt, men aktivt benektet. Hun sa hun var villig til det meste for å være med på å konkurrere. Men i praksis viste hun liten evne eller vilje til å normalisere vekten. Behandlerne opplevde ingen reell behandlingsallianse.

De idrettslig ansvarlige og de medisinsk ansvarlige klarte i begynnelsen ikke å få til et godt nok samarbeid. Ledere og trenere kviet seg for å gi den spisevegrende de treningsrestriksjoner og konkurransenekten som det medisinske teamet foreslo. Kommunikasjonen var for dårlig og ansvar ikke tydelig nok definert. B fikk uklare og til dels motstridende beskjeder, og i ettertid innrømmet hun at hun aktivt utnyttet en slik ubesluttsomhet. B representerte også en utfordring for lagkulturen, bl.a. ved at hun på samlinger og i mesterskap unngikk flere av fellesmåltidene.

Alvorlige spiseforstyrrelser er vanligere i idrett enn i normalpopulasjonen (18). Idrettsutøveren med anoreksi representerer flerfoldige utfordringer. Dels er det vanskene med terapeutisk allianse der utøveren benekter sykdom eller mangler sykdomsinnsikt. Dels er det vanskene med å vurdere når idrettslig aktivitet er et uttrykk for selve psykopatologien og bidrar til å opprettholde denne. Og dels er det vanskene med å skape klar kommunikasjon om slike tilfeller, særlig når ledelsen opplever at utøveren leverer gode prestasjoner. Hvem har det endelige ansvaret?

Det er viktig at støtteapparatet har et perspektiv som også strekker seg utover enkeltutøveren og dennes helse. Man må tenke på hele lagets og miljøets trivsel, kultur og helse. Utfordringene er særlig store i juniorkulturene. Her møter vi unge 
mennesker i sårbare livsfaser, som lett lar seg påvirke av hverandre. Det er vår klare erfaring at kompetansen i støtteapparatet er gjennomgående mindre her enn hos voksne utøvere på toppnivå.

\section{Psykoterapi og idrett}

Prestasjonene til utøver $C$ varierte påfallende sterkt. C kunne fortelle om bulimisk atferd de siste årene. I dårlige perioder var det daglig overspising og renselse i form av oppkast. Vekten svingte, og hun var «alltid» på slankekur.

I samtaler med psykiater ble det arbeidet parallelt med den praktiske administrasjonen av mat og trening, i tett samarbeid med ernæringsfysiolog. Man gikk i tillegg systematisk igjennom det å beskrive, forstå og mestre følelser og interpersonlige forhold. En god stund gikk det fortsatt opp og ned for $C$, men gradvis kom bedringen.

Da behandlingsforholdet opphørte etter noen år, var hun symptomfri. Den gode kontakten med ernæringsfysiologen fortsatte. I forløpet var det et begrenset antall fellessamtaler med hovedtrener. Disse handlet mest om at det var nyttig at trenerteamet hadde noe kunnskap om den medisinske situasjonen, innenfor hva $C$ selv definerte som hensiktsmessig. Det handlet også om arbeidsfordeling, med vekt på hva trenere ikke skulle blande seg inn i og kommentere. Den gradvise bedringen av spiseforstyrrelsen falt sammen med jevnere og bedre prestasjoner innen idretten.

Vi mener psykoterapeutisk kompetanse bør være en sentral del av den samlede kompetansen i et kvalifisert helsetilbud for toppidrettsutøvere. Det tilbys høykvalifisert psykoterapi innen de ordinære servicetilbudene, men vi vil påstå at man der raskt mister blikket for det spesifikke ved både å være en toppidrettsutøver og en person med alvorlige spiseforstyrrelser. Vår erfaring er at spesifikk kompetanse på spiseforstyrrelser i idrett samt mulighetene for tett samarbeid med ernærings- og treningsekspertise fremmer samarbeid, motivasjon og terapeutisk allianse.

\section{Helse og prestasjon}

Ernæring og spiseproplemer kan være vanskelige å ta opp fordi de er skambelagte fenomener, men også fordi åpenhet praktisk kan få negative konsekvenser, for eksempel at man ikke blir tatt ut på laget eller blir satset på.

Kasuistikkene viser også toppidrett som en arena for terapeutisk virksomhet (19). Teamene ved Olympiatoppene har årelang erfaring med både individuelle, par-, familie- og nettverkssamtaler samt intervensjoner på lagnivå. På lagnivå satser man på å bedre gruppekulturen rundt mat og følelser, finne ut hva som virker og hvordan man kan hjelpe hverandre til bedre prestasjoner. Det går også ut på å få utøvere, trenere og ledere til å hjelpe hverandre til å se hva som hemmer.

Erfaringene med medier er tvetydige. På den ene siden er det nyttig og nødvendig med oppmerksomhet på alvorlige fenomener som spiseproblemer i idretten. De skal ikke hemmeligholdes eller tabuiseres. Men det gjøres ikke alltid på riktig måte. Toppidrettsutøvere er kjendiser, og oppslag har en tendens til å bli tabloid konfliktorienterte og med liten forståelse for fenomenenes kompleksitet. Vi har erfart at slik fokusering har økt terskelen for å ta kontakt med eller ta imot tilbud om kontakt fra våre team.

Idretten speiler samfunnet. Å forstå folk og følelser blir viktigere på stadig flere arenaer. Dette preger og vil prege idretten fremover. Toppidrett handler om å vinne marginene. Mye handler om fysikk og teknikk, som treningsmengder, treningsteknikker og forhold som for eksempel skismøring. En sentral utfordring for fremtidens idrett er at fagfelter som prestasjonsernæring, idrettsfysiologi, psykologi, psykiatri, psykoterapi og trenernes relasjonskompetanse blir til en sunn og nyttig helhet. I idrettslige, og især toppidrettslige sammenhenger, er det alltid behov for et dobbeltperspektiv: helse og prestasjon. Ut fra etiske premisser må helse alltid komme foran prestasjon, men praktisk erfaring tilsier at helse og prestasjon som regel spiller best sammen.

De omtalte idrettsutøverne har gitt tillatelse til at artikkelen blir publisert.

\section{Finn Skårderud (f. 1956)}

er spesialist i psykiatri, dr.med. og professor ved Institutt for spesialpedagogikk, Universitetet i Oslo, overlege ved Oslo universitetssykehus og jobber deltid som psykiater ved Olympiatoppen i Oslo.

Forfatter har fylt ut ICMJE-skjemaet og oppgir ingen interessekonflikter.

\section{Terje Fladvad (f. 1963)}

er spesialist i psykiatri, overlege ved Regional avdeling for spiseforstyrrelser, Oslo universitetssykehus og jobber deltid som psykiater ved Olympiatoppen i Oslo.

Forfatter har fylt ut ICMJE-skjemaet og oppgir ingen interessekonflikter.

\section{Ina Garthe (f. 1973)}

er ph.d. i idrettsvitenskap og jobber ved Norges idrettshøgskole og som daglig leder for Olympiatoppens ernæringsavdeling i Oslo.

Forfatter har fylt ut ICMJE-skjemaet og oppgir ingen interessekonflikter.

\section{Heidi Holmlund (f. 1976)}

har mastergrad i klinisk ernæring og jobber som klinisk ernæringsfysiolog ved Olympiatoppen i Oslo

Forfatter har fylt ut ICMJE-skjemaet og oppgir ingen interessekonflikter.

\section{Lars Engebretsen (f. 1949)}

er spesialist i ortopedi, dr.med. og professor ved Universitetet i Oslo, Oslo universitetssykehus og Norges idrettshøgskole. Han er også tilknyttet Olympiatoppen i Oslo.

Forfatter har fylt ut ICMJE-skjemaet og oppgir ingen interessekonflikter.

\section{Litteratur}

1. Krentz EM, Warschburger P. A longitudinal investigation of sports-related risk factors for disordered eating in aesthetic sports. Scand J Med Sci Sports 2011; n/a.

2. Beals KA, Meyer NL. Female athlete triad update. Clin Sports Med 2007; 26: 69-89.

3. Garthe I. Vektregulering blant landslagsutøvere i vektklasseidretter i Norge. Rapport. Oslo: Olympiatoppen, 2005

4. Alderman BL, Landers DM, Carlson J et al. Factors related to rapid weight loss practices among international-style wrestlers. Med Sci Sports Exerc 2004: 36: 249-52

5. Steen SN, Brownell KD. Patterns of weight loss and regain in wrestlers: has the tradition changed? Med Sci Sports Exerc 1990: 22: 762-8.

6. Artioli GG, Gualano B, Franchini E et al. Prevalence, magnitude, and methods of rapid weight loss among judo competitors. Med Sci Sports Exerc 2010; 42: 436-42.

7. World Health Organization. ICD-10. Psykiske lidelser og atferdsforstyrrelser. Oslo: Gyldendal Akademisk, 2000

8. American Psychiatric Association. Diagnostic and statistical manual of mental disorders. 4. utg. Washington DC: American Psychiatric Association, 1994

9. Skårderud F, Fladvad T, Garthe I et al. Den dårlig ernærte idrettsutøveren - retningslinjer for tiltak. Tidsskr Nor Legeforen 2012; 132: xx-xx. E-publisert 8.8. 2012.

10. Skårderud F, Fladvad T, Garthe I et al. Den dårlig ernærte utøveren. Vektreduksjon, kroppsmodifikasjon og spiseforstyrrelser i toppidrett. Retningslinjer for holdning og handling. Oslo: Olympiatoppen 2012. www.olympiatoppen.no/fagomraader/helse/ aktuelt/page6807.html (13.8.2012)

11. Skårderud F. Gutter har også kropper. Om mat, maskulinitet og problematiske kroppspraksiser. Tidsskr Nor Psykologforen 2007; 44: 2-3. www.psykologtidsskriftet.no/ index.php?seks id=7587\&a=2 (13.8.2012)

12. Loucks AB. Energy balance and body composition in sports and exercise. J Sports Sci 2004: 22: 1-14.

13. Karila TA, Sarkkinen P, Marttinen M et al. Rapid weight loss decreases serum testosterone. Int J Sports Med 2008; 29: 872-7.

14. Strauss RH, Lanese RR, Malarkey WB. Weight loss in amateur wrestlers and its effect on serum testosterone levels. JAMA 1985; 254: 3337-8.

15. Wheeler GD, Wall SR, Belcastro AN et al. Reduced serum testosterone and prolactin levels in male distance runners. JAMA 1984: 252: 514-6.

16. Smathers AM, Bemben MG, Bemben DA. Bone density comparisons in male competitive road cyclists and untrained controls. Med Sci Sports Exerc 2009: 41: 290-6

17. Hetland ML, Haarbo J, Christiansen C. Low bone mass and high bone turnover in male long distance runners. J Clin Endocrinol Metab 1993; 77 : $770-5$.

18. Sundgot-Borgen J, Klungland M, Skårderud F. Spiseforstyrrelser i idretten. Tidsskr Nor Lægeforen 2004; 124: 2126-9.

19. Skårderud F. Coaching. Om betydningen av gode relasjoner i idrett. Norsk Idrettsmedisin 2003; 18 $17-8$.

Mottatt 21.11. 2011, første revisjon innsendt 19.3. 2012, godkjent 16.8. 2012. Medisinsk redaktør Siri Lunde. 